\title{
PERENCANAAN PEMBUATAN REAKTOR BIOGAS DAN PUPUK ORGANIK
}

\author{
THE DESIGN FOR BIOGAS REACTOR AND \\ ORGANIC FERTILIZER MANUFACTURING
}

\author{
Hermain Teguh Prayitno \\ Kantor Penelitian dan Pengembangan Kabupaten Pati \\ Email : hermainteguh70@gmail.com
}

Naskah Masuk: 29 Maret 2015 Naskah Revisi: 8 April $2015 \quad$ Naskah Diterima: 22 April 2015

\begin{abstract}
Indonesian economic state has not been stable yet, so that in the short term period, it can affect community's food sustainability, especially for farmer. Independency regarding energy and fertilizer need to be reached through the ability to process cow dung becoming biogas and fertilizer. The follow-up of previous research resulted a guidance to set a processing tool and a procedure to set a biogas processing. It is needed $33 \mathrm{~kg}$ of cow dung (equal to two adult-cow dung) and results 600 liters of biogas, 12,2 liters of liquid fertilizer, and $24.4 \mathrm{~kg}$ of solid manure per day.
\end{abstract}

Keywords: biogas, cow dung, organic fertilizer.

\begin{abstract}
ABSTRAK
Saat ini perekonomian indonesia belum stabil, dalam jangka pendek akan mampu mengganggu ketahanan pangan masyarakat, khususnya petani dan peternak. Kemandirian energi dan pupuk diharapkan segera bangkit melalui kemampuan sendiri mengolah feses sapi menjadi biogas dan pupuk. Kelanjutan dari hasil penelitian terdahulu mampu menghasilkan panduan masyarakat dalam merakit alat pengolah dan tata cara operasi dalam bentuk perencanaan pengolahan biogas dan pupuk. Bahan baku 33Kg ( setara dengan dua ekor sapi dewasa) setiap hari direncanakan diolah menjadi biogas 600 liter, pupuk cair 12.2 liter, dan ampas basah $24.4 \mathrm{Kg}$ setiap hari.
\end{abstract}

Kata Kunci : feses sapi, biogas, pupuk organik

\section{PENDAHULUAN}

Menipisnya sumberdaya mineral dan energi global, serta kemampuan menurunkan daya dukung lingkungan akibat energi fosil, mengharuskan pemerintah dan masyarakat mulai mengembangkan energi alternatif ramah lingkungan. Menurut Wahyudi (2013), strategi pengembangan biogas dapat dilakukan dengan penambahan biogas dengan skema pembiayaan swadaya masyarakat, lembaga donor, dan pemerintah. Kondisi tersebut menjadi gambaran bahwa pengadaan bangunan biogas belum mampu diusahakan oleh peternak sendiri,dimana pada umumnya mereka mengalami kendala dalam hal pembiayaan. Keadaan ini terlihat dari belum adanya bangunan biogas baru yang dibangun oleh peternak dengan dananya sendiri. 
ini $\begin{gathered}\text { Rumusan masalah dalam penelitian } \\ \text { adalah bagaimana cara }\end{gathered}$ mengimplementasikan hasil penelitian menjadi bentuk penelitian berupa desain perencanaan pengolahan feses sapi menjadi biogas, sekaligus menghasilkan pupuk cair dan pupuk padat yang mudah dan dapat dikembangkan oleh masyarakat. Tujuan penelitian ini adalah untuk 1) Mengetahui hasil penelitian lanjutan dari penelitian sebelumnya tentang biogas yang dapat secara sederhana diaplikasikan yaitu berupa perencanaan alat pengolahan feses (feses) sapi menjadi biogas dan pupuk; 2) Mengetahui cara perakitan dan cara operasional alat tersebut.

\section{TINJAUAN PUSTAKA}

Pemanfaatan feses sapi sebagai bahan baku biogas sudah banyak diterapkan di berbagai daerah di Indonesia. Pada proses biogas dihasilkan limbah biogas berupa slurry yang masih dapat dimanfaatkan sebagai pupuk organik. Dalam perkembangannya, banyak ditemukan kendala baik dalam proses pembuatan maupun perawatannya. Sehingga diperlukan adanya strategi pemanfaatan feses sapi dengan biogas. Menurut Prayitno (2014), strategi pemanfaatan feses sapi dengan biogas dipengaruhi oleh faktor internal dan eksternal yang dinilai dengan hasil 2,38 dan 2,92 pada posisi strategi pertumbuhan melalui integrasi horisontal dan stabilitas yaitu menggiatkan dan menginovasi proses pembuatan biogas, pupuk cair dan pupuk padat menjadi lebih mudah, murah dan dapat ditiru untuk mencukupi kebutuhan sendiri, dan menuju ketahanan peternak dan petani dalam menghadapi pencabutan subsidi pupuk.

Selama ini reaktor biogas yang umum digunakan adalah reaktor dengan ukuran dan volume isian yang besar, dimana dalam reaktor itu harus dipenuhi oleh feses sapi dari beberapa ekor sapi untuk menghasilkan gas metan. Penelitian mengenai energi dan pupuk organik dari biogas sudah banyak dilakukan dan diterapkan, akan tetapi minat masyarakat untuk membuat energi dan pupuk organik ini belum ada. Hal ini disebabkan oleh biaya yang besar, prosesnya yang rumit, dan nilai ekonominya rendah. Volume air yang besar pada pengolahan biogas mengharuskan kita untuk membangun reaktor biogas dengan volume besar. Hal ini tentu saja akan memberatkan peternak terkait dengan biaya yang harus dikeluarkan. Penelitian Prayitno (2014) menyatakan bahwa volume air yang digunakan untuk biogas dapat diturunkan dengan mengembalikan cairan slurry ke dalam reaktor dan kemudian memisahkan cairan dan padatan slurry untuk dimanfaatkan sebagai pupuk. Dari penelitian ini dihasilkan komposisi yang paling baik yaitu feses sapi $58 \%$, cairan slurry $27 \%$ dan penambahan air hanya $15 \%$. Proses fermentasi membutuhkan waktu 38 hari dan mampu menghasilkan biogas $0,561 / \mathrm{kg}$ feses.

\section{METODOLOGI PENELITIAN}

Perencanaan desain pengolahan dilakukan di Kantor Penelitian dan Pengembangan Kabupaten Pati dengan waktu perencanaan mulai bulan Februari sampai dengan Maret 2014. Metode penelitian menggunakan deskriptif kuantitatif melalui perhitungan data hasil penelitian. Hasil penelitian ini ditujukan pada peternak sapi, khususnya peternak kecil yang memiliki sapi $2-3$ ekor sapi dan mampu menghasilkan biogas untuk memasak satu keluarga setiap hari.

\section{Alat dan Bahan}

Alat:

Peralatan penelitian yang digunakan pada penelitian sebelumnya berskala laboratorium yaitu menggunakan pralon 4 inch, panjang 1 meter dan volume 7 liter yang dilengkapi dengan 
dopen 4 inch dan selang penangkap gas. Penambahan penyekat feses dengan dua buah dopen 2,5 inch di dalam pralon 4 inch. Penyekat feses ini diletakkan pada jarak yang sama dengan maksud untuk membagi ruang sehingga feses terbagi merata dari bawah sampai ke atas. Hal ini dilakukan berdasarkan temuan pada percobaan pra penelitian alat dan bahan sebelumnya, bahwa jika tanpa penyekat maka feses akan diangkat oleh biogasnya sendiri ke atas sehingga menjadi rapat dan menghalangi gas menuju selang penampung gas. Penampung gas pada penelitian ditujukan untuk pembacaan hasil volume gas setiap hari dan mengetahui berapa lama produksinya.

\section{Bahan:}

- feses sapi sebanyak 3,5 liter

- cairan slurry sebanyak 1 liter

- air sebanyak 1,5 liter

\section{PERHITUNGAN DAN PEMBAHASAN}

\section{Dasar Perhitungan}

Dasar perhitungan menggunakan formulasi hasil penelitian Prayitno (2014) yaitu $58 \%$ feses sapi, $27 \%$ air, dan $15 \%$ starter (cairan slurry) yang bertujuan untuk mengetahui kuantitas biogas dan pupuk. Akan tetapi penerapannya menggunakan cara kontinyu dimana penambahan cairan slurry tidak dilakukan karena bakteri telah ada dan tersedia di dalam reaktor. Akan tetapi sebelum cara ini dilakukan maka harus didahului dengan penumbuhan starter yang akan dibahas selanjutnya. Penyediaan starter menentukan tingkat campuran bahan baku yaitu 3,5 liter feses sapi dan 1,5 liter air.

\section{Bahan Baku}

Bahan baku yang digunakan adalah feses sapi dengan target produksi biogas 600 liter per hari. Waktu tinggal reaksi biogas ditentukan 38 hari. Feses sapi yang dibutuhkan dalam satu reaktor sebanyak $66 \%$ yaitu 32,8 atau $33 \mathrm{~kg}$ setiap harinya.
Sedangkan $33 \%$ nya berupa penambahan air sebanyak 16,4 liter atau 17 liter. Satu ekor sapi rata-rata mengeluarkan feses 15 $\mathrm{kg} /$ hari sehingga dibutuhkan 2 ekor sapi untuk menghasilkan feses sapi $30 \mathrm{~kg} / \mathrm{hari}$.

\section{Alat Pengolah Feses Sapi}

Reaktor Biogas

Perhitungan volume reaktor diperoleh dari total volume yang dibutuhkan untuk feses sapi, air, dan ruang penangkap gas. Volume feses sapi 32,8 atau $33 \mathrm{~kg}$ atau liter selama 38 hari menjadi 1.250 liter. Volume air 16,4 atau 17 liter selama 38 hari sebesar 625 liter. Volume bahan feses sapi 1.250 liter dan air 625 liter maka volume bahan sebesar 1.875 liter. Jika ruang penangkap biogas adalah satu per tujuh volume bahan maka hasilnya 267 liter, maka total volume reaktor antara bahan dan ruang penangkap sebesar 2.142 liter dan tersedia bahan reaktor di pasaran adalah tandon bervolume 2.200 liter, maka ruang penangkap biogas diperbesar menjadi 325 liter.

Tandon Penampung Biogas

Penampungan produksi biogas dipisahkan dengan reaktor biogas dikarenakan tiga alasan yang mendasar yaitu 1) Penggunaan ruang biogas di dalam reaktor biogas akan mengurangi ruang reaktor selama proses produksi biogas. Artinya penambahan volume biogas akan mengurangi volume bahan reaksi sehingga slurry yang keluar masih dalam keaadaan aktif. Hal ini sering kita jumpai adanya hasil pengolahan biogas yang menghasilkan slurry yang masih bau; 2) Produksi biogas di dalam ruang reaktor akan menaikkan tekanan reaktor yang dapat mengakibatkan kebocoran reaktor, sehingga untuk pengadaan bahan yang murah hasilnya akan bocor; 3) Limbah sisa yang masih bau harusnya 
tetap di berada dalam reaktor hingga kandungan gasnya habis (sudah tidak berbau).

Tampungan Produk Pupuk

Pupuk cair diperoleh setelah penyaringan slurry dan hasil pengepresan slurry sebanyak $370 \mathrm{ml} / \mathrm{kg}$ feses maka diperkirakan akan menghasilkan 12,2 liter cairan slurry dari $33 \mathrm{~kg}$ feses sapi. Maka dalam keadaan reaksi yang sudah normal diperkirakan mendapatkan cairan slurry 122 liter setiap sepuluh hari dan harus segera diaplikasikan sebagai pupuk cair organik untuk penyemprotan tanaman supaya tidak membutuhkan wadah penyimpan yang besar.
Pupuk padat slurry berasal dari sisa basah hasil pengepresan. Hasil pengepresan ini dapat ditampung dalam tanah dengan perhitungan 740 gr basah per kilogram feses sapi sehingga didapatkan 24,4 kg setiap hari dari $33 \mathrm{~kg}$ feses sapi. Pembuatan galian tanah untuk menampung ampas slurry seluas $1 \mathrm{~m}^{3}$ untuk tampungan ampas slurry selama 40 hari. Dengan menggali 2 lubang atau 3 lubang maka akan mampu menampung 80 sampai 120 hari ampas slurry. Dengan perlakuan ini, dimungkinkan ampas basah telah mengalami kondisi siap tebar dengan waktu tinggal 60 hari. Skema proses produksi biogas dan pupuk organik disajikan pada Gambar 1.

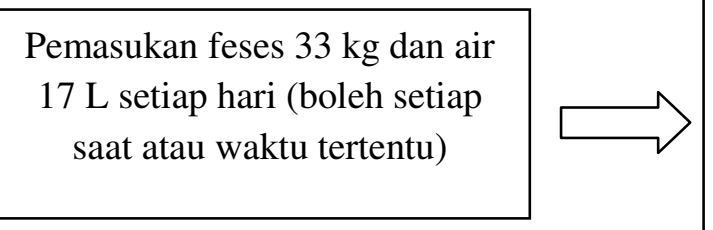

Reaksi metanansi 38 hari di dalam reaktor $2200 \mathrm{~L}$ menghasilkan :

1. Biogas

2. Slurry

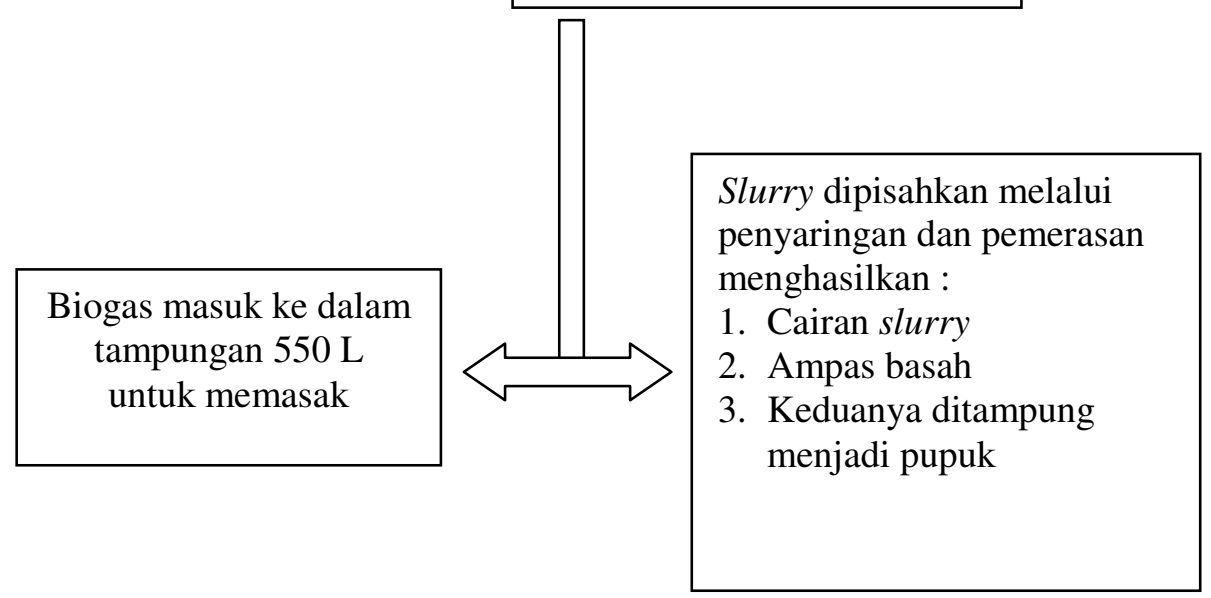

Gambar 1.

Skema Proses Produksi Biogas dan Pupuk Organik

Sumber: Hasil Pengamatan (2014) 


\section{Perakitan Alat}

Peralatan yang digunakan pada penelitian ini berasal dari peralatan dan bahan lokal. Hal tersebut bertujuan agar alat ini dapat dengan mudah Ukuran dan jenis peralatan disajikan pada Tabel 1 .

\section{Tabel 1.}

Peralatan dan Asesoris

\begin{tabular}{|c|c|c|c|}
\hline Unit & Peralatan & Aksesoris & Keterangan \\
\hline \multirow[t]{3}{*}{ Reaktor } & $\begin{array}{l}\text { Tandon } 2200 \mathrm{~L} \\
-\quad \text { inlet }\end{array}$ & $\begin{array}{l}\text { - Ember } 20 \mathrm{~L} \\
\text { - Pralon } 2,5 \text { inch } \\
\text { - Knee 2,5 inch } \\
\text { - Watermoor 2,5 inch }\end{array}$ & $\begin{array}{l}\text { Ember untuk masuknya feses dan air } \\
\text { menuju reaktor melalui peralon }\end{array}$ \\
\hline & - $\quad$ Ruang reaksi & $\begin{array}{l}\text { - Peralon } 1 \text { inch } \\
\text { - Knee dan tee } 1 \text { inch } \\
\text { - Pralon 2,5 inch } \\
\text { - SDD dan SDL 3/4 } \\
\text { inch } \\
\text { - Rajutan bambu } \\
\text { (barscreen) }\end{array}$ & $\begin{array}{l}\text { Dibagi } 4 \text { ruang: } \\
\text { 1. Bawah tempat feses kasar disekat } \\
\text { dengan barscreen bambu spasi jarak } \\
\text { lebar. } \\
\text { 2. Tengah tempat feses tersaring } \\
\text { awal dan disekat dengan barscreen } \\
\text { bambu spasi jarak sedang } \\
\text { 3. Atas tempat feses lembut } \\
\text { dihalangi anyaman bambu sangat } \\
\text { lembut dan menyamping menuju luar } \\
\text { reaktor } \\
\text { 4. Ruang kosong penangkap gas }\end{array}$ \\
\hline & - Outlet & $\begin{array}{l}\text { - Pralon } 2,5 \text { inch } \\
\text { - Knee } 2.5 \text { inch } \\
\text { - Watermoor } 2.5 \text { inc } \\
\text { - Penyaring } \\
\text { - Pengepres } \\
\text { - Pralon gas } 3 / 4 \text { inch }\end{array}$ & $\begin{array}{l}\text { Sisa slurry setelah berumur } 38 \text { hari } \\
\text { mengalir menuju tempat penyaringan } \\
\text { selama } 24 \text { jam dan dilanjutkan } \\
\text { pengepresan dengan batu }\end{array}$ \\
\hline Biogas & Tandon $550 \mathrm{~L}$ & $\begin{array}{l}\text { - Knee 3/4 inch } \\
\text { - Stop kran 3/4 inch } \\
\text { - Kayu/bambu } \\
\text { - Pengungkit } \\
\text { - Kompor gas }\end{array}$ & $\begin{array}{l}2 \text { tandon dilakukan pemotongan } \\
\text { bagian atas untuk tampungan air } \\
\text { penahan gas dan bagian bawah untuk } \\
\text { tandon penampung gas. Pemasukan } \\
\text { dan pengelularan melalui bawah } \\
\text { tandon air supaya tidak mengganggu } \\
\text { pergeseran ke atas ( ketika produksi } \\
\text { biogas ) dan ke bawah ( ketika } \\
\text { mengalirkan gas ke kompor ) tandon } \\
\text { penampung gas }\end{array}$ \\
\hline
\end{tabular}

Sumber: Hasil Pengamatan (2014) 


\section{Uji Kebocoran}

Pengujian kebocoran air maupun biogas pada reaktor dapat dilakukan dengan cara berikut: 1) Pelubangan inlet dan outlet tandon sekaligus pemasangan pralonnya; 2) Pemasangan tutup tandon yang rapat dan masukkan air hingga tumpah pada outletnya; 3) Dibiarkan sehari; 4) Pemasukkan kembali air sebanyak satu ember. Jika dapat mengeluarkan air sama satu ember, atau kurang sedikit maka kemungkinan bocor gas, dan jika kurang banyak maka kemungkinan bocor air.
Penampung biogas juga harus di uji, akan tetapi hal ini dapat diketahui langsung melalui bau biogas, penurunan penampung biogas, dan atau kenaikan penampung yang tidak seperti biasanya.

\section{Pengolahan Feses sapi}

Prosedur pembuatan starter bakteri perombak feses sapi dapat dilakukan dengan mencampur feses sapi dengan perbandingan 1: 1 selama 9 (Prayitno, 2014 dan Tuwuilu dkk, 2014). Proses perencanaan pembuatan peralatan pengolahan feses sapi disajikan pada gambar 2.

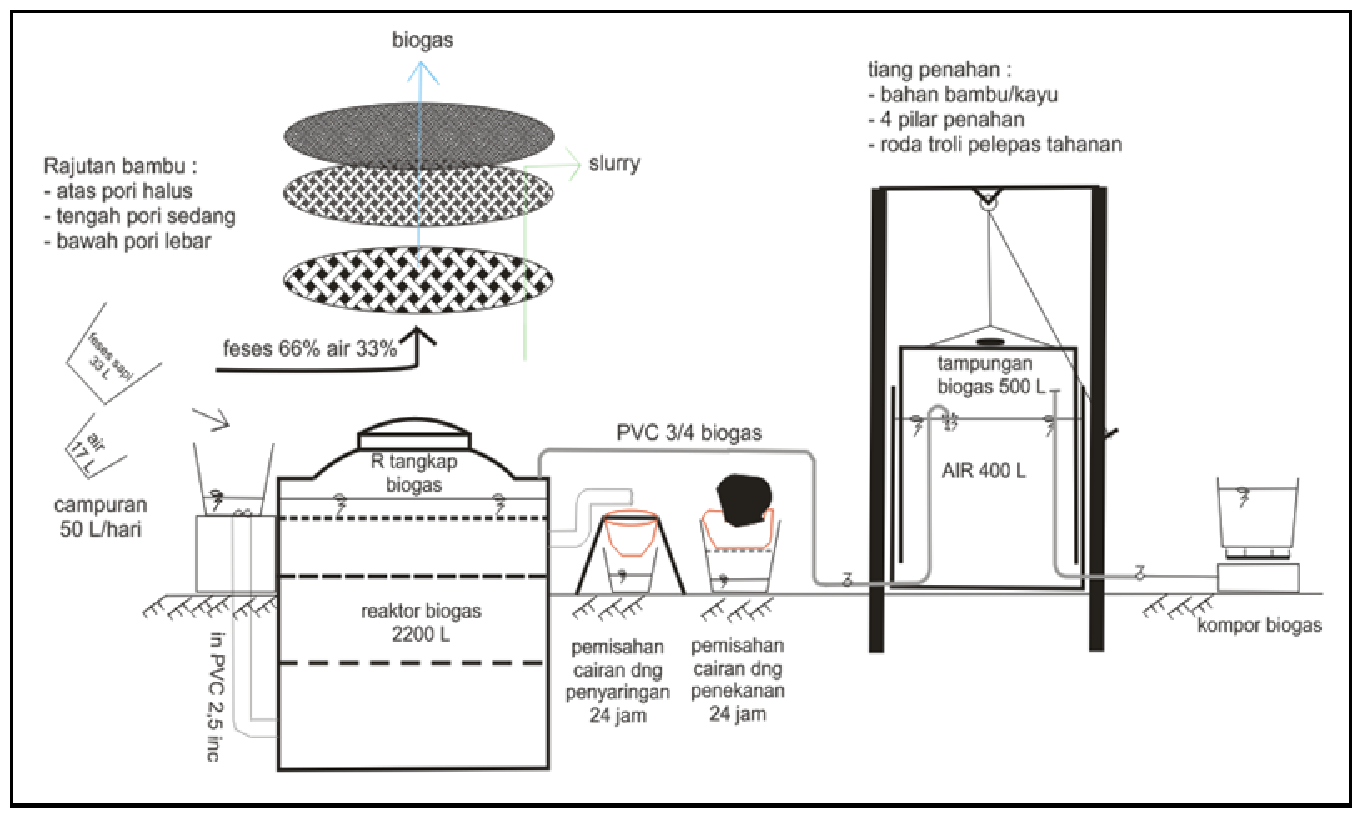

Gambar 2.

Pengolahan Feses Sapi

Sumber: Hasil Perencanaan (2015)

Pada penelitian ini, pencampuran feses sapi dan air dilakukan sepertiga volume reaktor yaitu sebesar 150 liter feses dan 150 liter air dibiarkan selama 9 hari. Pengecekan adanya pertumbuhan bakteri perombak atau starter dapat dilakukan dengan pembauan metan, jika ada bau metan maka dilanjutkan dengan pemberian setiap hari secara rutin.

Prosedur operasional pengolahan feses sapi (feses) sapi sebesar $33 \mathrm{~kg}$ dengan air sebesar 17 liter dapat dilakukan dua kali. Pemberian pakan dan pembersihan kandang dua kali sehari 
dapat dilanjutkan dengan memasukkan feses ke dalam reaktor biogas.

Prosedur pengambilan hasil biogas dilakukan setelah tandon biogas penuh dengan membuka kran menuju kompor dan kemudian menyalakannya. Sedangkan hasil pupuk cair dan pupuk padat selalu dilakukan setiap hari ketika ember saringan slurry telah berumur 24 jam yang dilanjutkan dengan proses penekanan menggunakan batu sehingga cairan pada feses dapat keluar lebih maksimal. Cairan tersebut kemudian ditampung untuk dimanfaatkan sebagai pupuk cair. Sedangkan ampas basahnya dimasukkan kedalam tanah untuk pengalami proses pemadatan yang pada akhirnya dapat dimanfaatkan sebagai pupuk padat.

\section{KESIMPULAN DAN SARAN}

\section{Kesimpulan}

Untuk mendapatkan biogas yang mencukupi kebutuhan memasak setiap hari satu keluarga sederhana membutuhkan total 600 liter biogas untuk pagi dan sore. Bahan baku feses sapi yang dibutuhkan sebesar $33 \mathrm{~kg}$ atau sekitar 2 ekor sapi dewasa dengan penambahan 17 liter air. Bahan yang dimasukkan ke dalam reaktor ini akan menghasilkan 12,2 liter cairan slurry untuk pupuk cair dan 24,4 kg ampas basah slurry sebagai pupuk padat.

\section{Saran}

Kesimpulan penelitian ini dapat direkomendasikan untuk perencanaan daerah guna mengatasi krisis energi dan pupuk pertanian dengan didahului pembuatan prototipe alat dan pemetaan calon desa percontohan mandiri energi dan pupuk di Kabupaten Pati.

\section{DAFTAR PUSTAKA}

Prayitno, H. T. 2014. Strategi Pemanfaatan Feses Sapi. Jurnal Litbang 10(1): 43-51.

Wahyudi, J. 2013. Strategi Pengembangan Biogas Pada Peternakan Sapi Perah. Jurnal Litbang 9(2): 121-127.

Tuwuilu, B. E., Rumambi, D. P., Rantung, R. A., Pinatik, H. F. 2014. Uji Tekni Biogas Dari Bahan Baku Feses Sapi di Desa Totabuan Kecamatan Lolak Kabupaten Bolaang Mongondow. Cocos 4(5).

\section{BIODATA PENULIS}

Hermain Teguh Prayitno, lahir 11 April 1970 di kota Rembang Jawa Tengah. Magister Ilmu Lingkungan dari Universitas Diponegoro (UNDIP) Semarang tahun 2008. Saat ini bekerja sebagai peneliti muda di Kantor Penelitian dan Pengembangan Kabupaten Pati. 